\title{
Genome instability in Chironomus annularius sensu Strenzke (Diptera, Chironomidae): A biomarker for assessment of the heavy metal contaminants in Poland
}

\author{
Paraskeva MICHAILOVA ${ }^{1 *}$, Julia ILKOVA ${ }^{1}$, Ewa SZAREK-GWIAZDA², Andrzej KOWNACKI ${ }^{2}$, Dariusz CISZEWSKI ${ }^{3}$ \\ ${ }^{1}$ Institute of Biodiversity and Ecosystem Research, Bulgarian Academy of Science, Tzar Osvoboditel 1 boulv., 1000 Sofia, Bulgaria; \\ ${ }^{2}$ Institute of Nature Conservation, Polish Academy of Sciences, al. Adama Mickiewicza 33, 31-120 Krakow, Poland; ${ }^{3}$ AGH-University \\ of Science and Technology, al Adama Mickiewicza 30, 30-059 Krakow, Poland \\ *Corresponding author: pmichailova@yahoo.com; michailova@zoology.bas.bg
}

\begin{abstract}
We studied the effect of heavy metal contaminations on genome instability of Chironomus annularius sensu Strenzke from three sampling sites on the River Chechło valley in southern Poland and a control site in Saraya, Bulgaria. The analysis of the heavy metal concentrations in sediments at the three river sites indicated concentrations higher than those in the fossil reference data ( $\mathrm{Zn}$ 83-160 times, Pb 64-250 times, and Cd 210-793). According to the geoaccumulation index (Igeo), the sediments at all Chechło stations were classified as extremely polluted (Igeo class 6) by $\mathrm{Cd}, \mathrm{Pb}$ and $\mathrm{Zn}$ while they were much less polluted by $\mathrm{Cu}$ (classes 1-3). The concentration of $\mathrm{Cd}, \mathrm{Pb}$ and $\mathrm{Zn}$ in the sediments studied exceeded 21-79, 11-44 and 18-34 times the toxic effect threshold (TET) respectively; therefore, the sediments potentially have detrimental effects on the fauna. Genome instability was determined by somatic structural chromosome alterations (mainly heterozygous inversions) in the salivary gland chromosomes of C. annularius. On the basis of the number and frequency of these aberrations the somatic (S) and cytogenetic (C) indices were calculated as these indices allow a better quantification of the impact of heavy metals on organisms living in sediments. In the three Chechło sampling sites somatic aberrations occurred at a frequency significantly higher than in the control site $(\mathrm{P}<0.001)$. The three Chechło samples possess a high spectrum of somatic rearrangements with $\mathrm{S}$ index varying from 1.5 to 2.23 while in control site, $\mathrm{S}$ is 1.08 . The $\mathrm{C}$ index of $C$. annularius from the polluted river sites varied from 0.163 to 0.380 , far in excess of the $\mathrm{C}$ value of the control site $(1.0)$, indicating strong pollution $(<0.5)$ according to previous studies. In addition, a high level of inherited aberrations was detected (19 inherited band sequences, two of which were new). In all river stations the inverted homozygous band sequences A2.2 occurred in a high frequency (85\%) and no standard sequences (A1.1) were observed. The transcription activity of Nucleolar Organizers (NORs) in chromosome arms A, C, E, G was often damaged and NOR activity was completely suppressed in $12.48 \%$ of larvae. Moreover, appearance of malformations in the external morphology of larvae was detected in $16.67 \%$ of larvae from all polluted sites. Therefore, the genome instability as estimated by two cytogenetic indices is a good biomarker of long-term toxicity and could be successfully implemented in the sediment monitoring procedures.
\end{abstract}

Key words: Chironomus annularius; genotoxicity; chromosome aberrations; biomarkers; heavy metals.

Received: October 2017. Accepted: December 2017.

This paper was presented at the $20^{\text {th }}$ International Symposium on Chironomidae, Trento, Italy, 2-8 July 2017. Session: Genetics and Cytogenetics.

\section{INTRODUCTION}

Metal mining and processing has been recognized as the largest anthropogenic source of heavy metals in the environment. Discharge of mine waters and drainage from adits affects river courses for many kilometers downstream (Byrne et al., 2012). Recently metal mining had markedly decreased in most western and middle European countries leaving tens of thousands of heavy metal contaminated sites where the quality of soil, sediment and ground- and surfacewaters has been seriously affected. Since ecotoxicological effects of heavy metals depend on numerous specific environmental factors, their assessment is considered to have crucial importance for mine-site management (Simpson and Batley, 2007).
Release of heavy metal contaminants in the environment causes their accumulation in biotic systems and can produce alterations both at individual and community level. In order to assess the effect of contaminants on the biota, it is very important to select a good method and a suitable group of organisms for monitoring or assessment of environmental impact. An abundant group of model insects successfully used for aquatic ecosystem contamination monitoring is the Chironomid family. Chironomid larvae are widely distributed in freshwater basins and have short life cycle. Their excellent salivary gland chromosomes make them suitable indicators of heavy metal genotoxicity at the individual level (Michailova et al., 2012) as contaminants can have a genotoxic effect, acting either on the DNA or 
altering chromosome structure (Al-Shami et al., 2013; Ilkova et al., 2014; Michailova et al., 2012, 2015, 2016). Our previous studies (Ilkova et al., 2014; Michailova et al., 2015, 2016) showed that genome instability can be assessed by two cytogenetic indices: Somatic (S) and Cytogenetic (C). The Cytogenetic index indicates the degree of pollution with three levels of pollution can be recognized: slightly polluted (0.9-0.8), moderate polluted (0.7-0.5) and highly polluted (<0.5) (Ilkova et al., 2014). The somatic index indicates the level of chromosome damage (Michailova et al., 2015). Both indices are very sensitive to cytogenetic effects of toxicants. Previous studies of Chironomus annularius demonstrated that the genome of this species displays chromosome alterations in contaminated water basins (Michailova and Hirvenoja, 2015; Ilkova et al., 2017) and can be a good model of anthropogenic stress. The aim of this paper is to evaluate the genome instability of $C$. annularius larvae in sediments contaminated by an abandoned $\mathrm{Zn}-\mathrm{Pb}$ mine using the somatic and cytogenetic indices.

\section{METHODS}

\section{Study area}

The Chechło River is situated in the Silesian-Cracow region of southern Poland. Zinc and lead mines in Trzebinia discharged mine waters into the Chechło River for nearly 50 years (1962-2010). Moreover, until the beginning of 21st century, the river water quality was influenced by industrial and municipal sewage effluents from two towns (Ciszewski, 1997). In the middle reach of the river there are small ponds of ca. 4 ha and up to $1 \mathrm{~m}$ deep (Fig. 1). This study was carried out at one station on the Chechło River (site 1), in the channel connecting pond with the river (site 2) and from the lowest pond (site 3) (Fig. 1). Site 2 was selected as exchange of water takes place between river and pond. Different morphology and flow conditions were the reason to select site 2 close to the site 3. C. annularius was a dominant species in all the Chechło River stations. The number of studied individuals, cells, date of collecting larvae and sediment samples can be seen in Tab. 1. For comparison, C. annularius larvae were also sampled from a less polluted site - a spring at Saraya (Pazardzhik) in Bulgaria which we considered as a control site. Here the concentrations of heavy metals were several times less compared with the other three sites and not so high compared with fossil sediment (Förstner and Salomons, 1980) (Tab.1).

\section{Chemical analysis}

Metal content of the sediment was analyzed by dissolution of $0.5 \mathrm{~g}$ of $<0.063 \mathrm{~mm}$ fraction in $10 \mathrm{~cm}^{3}$ of $65 \% \mathrm{HNO} 3$ and $2 \mathrm{~cm}^{3}$ of $30 \% \mathrm{H}_{2} \mathrm{O}_{2}$ (both analytical grade) using a microwave digestion technique. The metal concentrations were measured by atomic absorption spectroscopy (AAS) using an apparatus Varian Spectra AA-20 equipped with a graphite furnace. To estimate the level of sediment contamination by heavy metals the

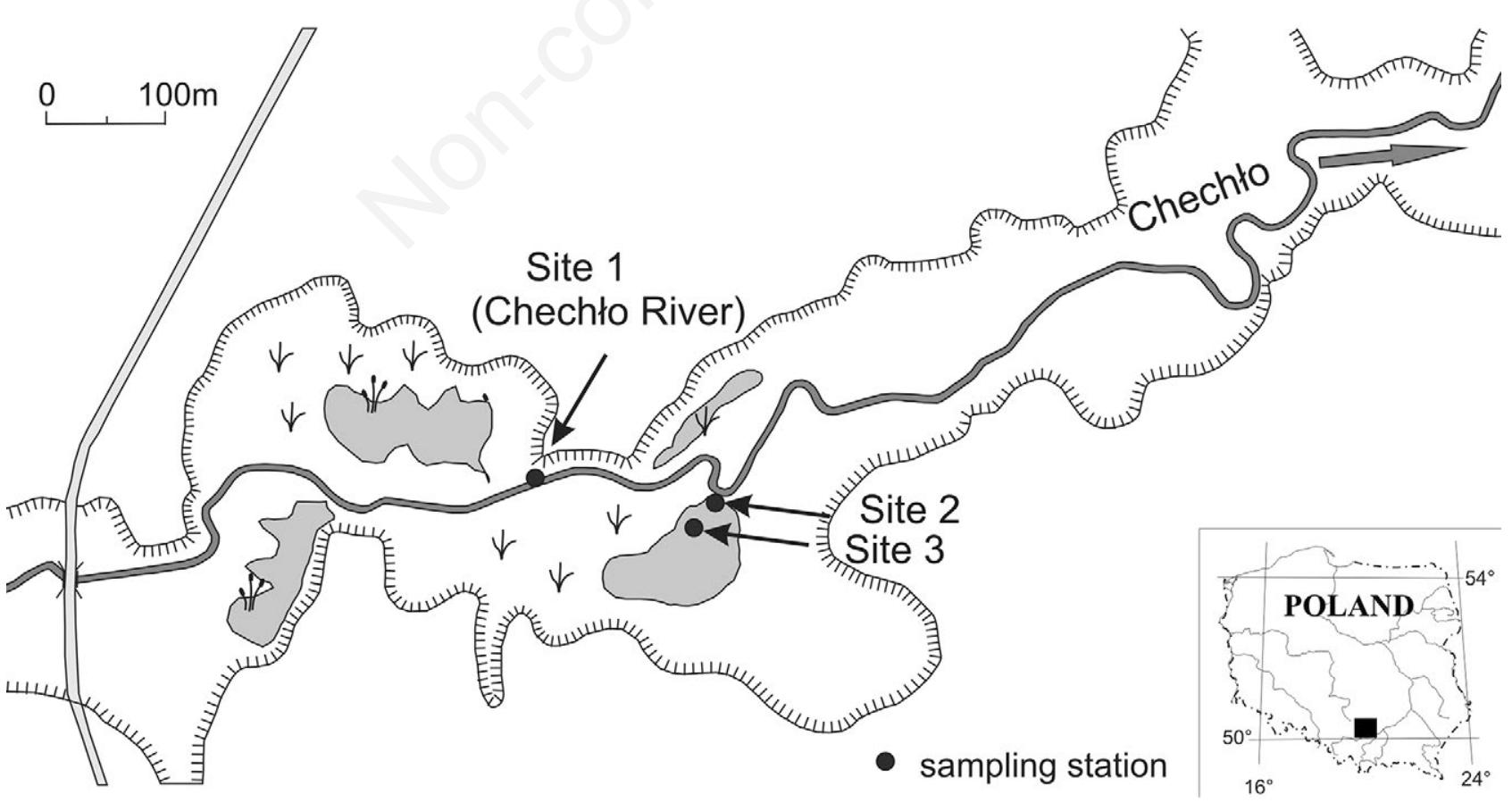

Fig. 1. Sampling sites of Chironomus annularius larvae and sediments. 
geoaccumulation index (Igeo) was calculated using the Müller (1981) equation: $\operatorname{Igeo}_{-} \log _{2}(\mathrm{Cn} / 1.5 \mathrm{Bn})$ where: $\mathrm{Cn}$ is the mean concentration of an element in the sampled sediment, and $\mathrm{Bn}$ is the geochemical background of the element in shale (Turiekian and Wedepohl, 1961). According to values of the Igeo, Müller (1981) described seven categories of sediment contamination from unpolluted (class 0 ; Igeo $\leq 0$ ) to extremely contaminated sediment (category 6 ; Igeo $\geq 5$ ).

\section{Larvae of $C$. annularius: morphological and cytogenetic analysis}

Larvae (IV instar) were fixed in alcohol: acetic acid (3:1). For the species identification we used the external morphology of the larva and species-specific cytogenetic markers in the salivary gland chromosomes (Kiknadze et al., 2012; Michailova and Hirvenoja, 2015). The chromosomes were mapped according to Keyl (1962) (for arms A, E, F) and Kiknadze et al. (2012) (for arms C and D). The chromosome arms B and $G$ were not mapped. The polytene chromosome preparations were made according to Michailova (1989). The larva head capsule and the rest of the larval body for every specimen were mounted for morphological analysis. Both sets of slides are retained at the Institute of Biodiversity and Ecosystem Research, Bulgarian Academy of Sciences.

\section{Indices and statistical analysis}

We estimated the percent frequency of every somatic aberration in the polytene chromosomes of $C$. annularius from all sites including the control. Inherited aberrations were presented as percentages considering every inherited band sequence as well as the number of individuals with heterozygous aberrations found in River Chechło sites and the control. Each aberration was localized precisely in the sections of the polytene chromosome map according to Kiknadze et al. (2012). The Somatic (S) and Cytogenetic (C) indices were calculated on the basis of somatic aberrations. A somatic index (S) was calculated for each site as the ratio of the number of different somatic aberrations relative to the number of studied individuals at that locality (Sella et al., 2004). The cytogenetic index (C) was estimated as the ratio of the average percent of somatic aberrations per individual in a control to average percent of somatic aberrations per individual at polluted site (Ilkova et al., 2014). The inherited aberrations were used in calculating the hereditary index $(\mathrm{H})$ which is an estimate of the degree hereditary variability of each studied site (Sella et al., 2004). According to these authors $\mathrm{H}$ was calculated as a ratio of the number of inherited aberrations in a site to the number of the individuals studied at that site. The naming of all band sequences followed that of Kiknadze et al. (2012). The number of somatic alterations in the polytene chromosomes of the larvae from every polluted site was compared to that of larvae from the control site using the $\mathrm{G}$ test. $\mathrm{P}<0.05$ and $\mathrm{P}<0.001$ were taken as significant.

\section{RESULTS}

\section{Sediment analysis}

The metal concentrations (as $\mu \mathrm{g} \mathrm{g}^{-1}$ ) in the sediments of sites 1, 2, 3 varied in the range: $\mathrm{Zn} 9581-18428, \mathrm{Cd} 63-$ 238, $\mathrm{Pb}$ 1932-7497 and $\mathrm{Cu}$ 94-293 and exceeded many times ( $\mathrm{Zn} 83-160$ times, $\mathrm{Pb}$ 64-250 times, and $\mathrm{Cd} 210$ 793 ) the reference data (Förstner and Salomons, 1980). Pond sediments were characterized by concentrations of metals higher than those of the river channel (Tab.1). The

Tab. 1. Number of studied individuals $(\mathrm{N})$ and cells of $C$. annularius, somatic $(\mathrm{S})$, cytogenetic $(\mathrm{C})$ and inherited $(\mathrm{H})$ indices, the concentrations of $\mathrm{Cd}, \mathrm{Pb}, \mathrm{Cu}$ and $\mathrm{Zn}$ in the sediments of the studied sites, values of geoaccumulation index (Igeo) and classes of contamination.

\begin{tabular}{|c|c|c|c|c|c|}
\hline Data & $\begin{array}{c}\text { Site } 1 \\
\text { May } 2016\end{array}$ & $\begin{array}{c}\text { Site } 2 \\
\text { May } 2016\end{array}$ & $\begin{array}{c}\text { Site } 3 \\
\text { May } 2016\end{array}$ & $\begin{array}{c}\text { Control } \\
\text { June } 2002\end{array}$ & $\begin{array}{c}\text { Fossil } \\
\text { sediment }\end{array}$ \\
\hline $\mathrm{N}$ of individuals & 14 & 21 & 13 & 12 & - \\
\hline $\mathrm{N}$ of cells & 367 & 389 & 281 & 275 & - \\
\hline $\mathrm{N}$ of somatic aberrations & 21 & 31 & 29 & 13 & - \\
\hline $\mathrm{N}$ of inherited aberrations & 5 & 7 & 7 & 5 & - \\
\hline $\mathrm{S}$ index & 1.5 & 1.48 & 2.23 & 1.08 & - \\
\hline $\mathrm{C}$ index & 0.38 & 0.163 & 0.193 & 1.00 & - \\
\hline H index & 0.357 & 0.333 & 0.538 & 0.358 & - \\
\hline 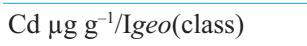 & $63 / 7.1(6)$ & $238 / 9.0(6)$ & $104 / 7.9(6)$ & $10 / 4.5(5)$ & $0.3 /-0.58(0)$ \\
\hline $\mathrm{Pb} \mu \mathrm{g} \mathrm{g}^{-1} /$ Igeo(class) & $1932 / 6.0(6)$ & $7497 / 8.0(6)$ & $3091 / 6.7(6)$ & $163 / 2.4(3)$ & $30 / 0(0)$ \\
\hline $\mathrm{Zn} \mu \mathrm{g} \mathrm{g}^{-1} /$ Igeo(class) & $958 / 6.1(6)$ & $18428 / 7.0(6)$ & $11129 / 6.3(6)$ & $216 / 0.6(1)$ & $115 /-0.31(0)$ \\
\hline $\mathrm{Cu} \mu \mathrm{g} \mathrm{g}^{-1} / \mathrm{Igeo}$ (class) & $94 / 0.5(1)$ & $293 / 2.0(3)$ & $100 / 1.6(2)$ & $26 /-1.4(0)$ & $51 /-0.4(0)$ \\
\hline
\end{tabular}

*Fossil sediment according to Föstner and Salomons (1980); classes of contamination according to Müller (1981). 
highest concentrations of all the metals were found at site 2. The sediments at all Chechło sites were extremely contaminated by $\mathrm{Cd}, \mathrm{Pb}$ and $\mathrm{Zn}$ (class 6 ) and less polluted by $\mathrm{Cu}$ (classes 1-3) according to Müller's classification (Tab. 1). The sediment of the control Saraya site showed elevated concentrations of $\mathrm{Cd}$ and $\mathrm{Pb}$ (Tab. 1) and no contamination by $\mathrm{Zn}$ and $\mathrm{Cu}$ (Tab. 1).

\section{Larval morphology}

The morphology of larvae did not differ from that described by Kiknadze et al. (2012) and Michailova and Hirvenoja (2015). However, in the polluted stations some larvae have malformations of the mandible and mentum: $21.42 \%$ of the larvae in site $1 ; 14.28 \%$ of the larvae in site $2 ; 15.38 \%$ of the larvae in site 3. Deformities of the mandible were expressed by asymmetry in the mandibular teeth while malformations of the mentum appeared either as a missing tooth or fused teeth. No malformations in control individuals were observed.

\section{Cytogenetic characteristic of $C$. annularius}

C. annularius has $2 \mathrm{n}=8$, belongs to thummi cytocomplex with arm combinations AB, CD, EF, G. Chromosomes AB, CD are metacentric, chromosome EF - submentacentric and chromosome G - telocentric (Fig. 2 a-d). The species has 5 Nucleolar Organizers (NORs) located in arms A, C, E and G and three Balbiani rings (BRs) in chromosome $\mathrm{G}$. The nucleoli in arms A, C, $\mathrm{E}$ and $\mathrm{G}$ are good species-specific cytogenetic markers for identifying the species at the cytogenetic level. In polytene chromosomes of $C$. annularius from all polluted stations we found cells where the NOR in arm A appeared either in heterozygous state $(2.17 \%)$ or not expressed (4.95\%). Moreover, in the three Chechło polluted sites a very interesting phenomenon was observed: the nucleoli in arms $\mathrm{C}$ and $\mathrm{E}$-species-specific markers- were not always expressed (in $0.54 \%$ and $6.99 \%$ of larvae, respectively) and in arm $\mathrm{E}$, the second NOR occurred in heterozygous state in $0.41 \%$ of larvae (Fig. 3e).

\section{Inherited chromosome aberrations}

Nineteen band sequences were observed in the Chechło River sites plus the control site. Inherited heterozygous aberrations detected in the studied species are included chromosome polymorphism and appeared in different frequency from $5 \%$ to $61 \%$. It was noted that the degree of polymorphism in different arms was not equal. No inherited heterozygous aberrations were detected in arms E and G. The most polymorphous were arms A, B, $\mathrm{C}$ and $\mathrm{F}$. Most of the inherited aberrations were in heterozygous state. Only in arm A in all sites on the river was an inversion in homozygous state observed (A2.2, section $13 \mathrm{ab}-12 \mathrm{cb}$, occurred in $85 \%$ ). No alternative standard sequences of arm A (A1.1) were found. The standard band sequences in arms B1.1, C1.1, D1.1, E1.1 and G1.1 dominated in all sites (between $76 \%$ and $100 \%$ ). The sequences A2, B2, C2 and F1 were observed in a homo-and heterozygous state (Fig. 3a). The most frequent heterozygous inversion occurred in arm F (section 16-17) in $61 \%$ of the larvae of site 3 . Two new band sequences in $\operatorname{arm} \mathrm{A}$ (A2.5, section - 17-19f) and arm C (C1.3, section-6hg-15c) were found in a heterozygous state only at the polluted site 3 and occurred with a frequency of $7.7 \%$ and $4.8 \%$ respectively. It is important to note that in all sites the level of chromosome polymorphism, realized by heterozygous inversions was high (site 1: $50 \%$; site 2 : $81 \%$; site 3: $77 \%$; control site: $84 \%$ ). The mean number of heterozygous inversions per individual was low (site 1: 0.86 ; site 2: 0.86; site 31: 1.15; control site: 1.17).

\section{Somatic structural and functional rearrangements}

In total 129 somatic structural aberrations localized in different sections of all salivary gland chromosomes of $C$. annularius were observed (Tab. 2). The aberrations affected few cells of every individual and were confined to a small region of the chromosomes. A wide spectrum of somatic rearrangements was observed: somatic heterozygous paracentric (Fig. 3b) and pericentric inversions, deficiencies and deletions (Fig. 3c). For the first time in this species a trisomy in the polytene chromosomes was detected (Fig. $3 d)$. From each of the three polluted stations, deletions in chromosome G (Fig. 3c) appeared at a significantly higher frequency than in the control station (site $1: \mathrm{G}=12.357$, $\mathrm{df}=1, \mathrm{P}<0.001$; site $2: \mathrm{G}=13.543, \mathrm{df}=1, \mathrm{P}<0.001$; site 3 : $\mathrm{G}=10.384, \mathrm{df}=1, \mathrm{P}<0.001)$. Chromosome damage in all arms of the polytene chromosomes of $C$. annularius occurred in larvae from the three polluted sites at significantly higher frequency than in larvae from the control site ( site 1: $\mathrm{G}=5.306, \mathrm{df}=1, \mathrm{P}<0.05$; site 2: $\mathrm{G}=68.348, \mathrm{df}=1, \mathrm{P}<0.001$; site $3: \mathrm{G}=39.072$, df $=1$, $\mathrm{P}<0.001)$. The $\mathrm{C}$ index values from the polluted Chechło River sites ranged between 0.163 and 0.380 . These values reveal a high degree of pollution having in mind that the study of Ilkova et al. (2014) showed that a C value $<0.5$ indicate a high level of pollution. Heavy metal pollution is also shown by Igeo (class 6 for heavy metals $\mathrm{Pb}, \mathrm{Cd}$, and $\mathrm{Zn)}$ (Tab. 1). The highly contaminated sediments induced a high level of chromosome damage as indicated by the $\mathrm{S}$ index which varied between 1.48 and 2.23 while in the control site the index was 1.08 (Tab. 1). Therefore, the results indicate of the $\mathrm{S}$ were higher in the species from polluted sites with respect to that of the control (Tab. 1 and Fig. 4). However, there is not a direct relationship between the degree of sediment contamination and the level of chromosome damage as indicated by $\mathrm{S}$ as the value is highest in site 3 whereas the concentrations of trace metal were less than site 2 (Fig. 4). 


\section{DISCUSSION}

The sediments from the River Chechło kilometers downstream of the disused mine remain heavily contaminated to a degree which is typical of freshwater sediments polluted by active and disused $\mathrm{Zn}$ and $\mathrm{Pb}$ mines (Audry et al., 2004; Adamu and Nganje, 2010; Ciszewski et al., 2013; Michailova et al., 2015). High heavy metal pollution was present also in the sediments of the pond where contaminants have been stored since the mining era. The level of contamination of the sediments of the three polluted sites was the highest according to Igeo (Müller, 1981). Moreover, $\mathrm{Cd}, \mathrm{Pb}$, and $\mathrm{Zn}$ concentrations exceed several times (21-79, 11-44, and 18-34 times, respectively) the values of toxic effect threshold TET (i.e., $\mathrm{Cd}=3, \mathrm{~Pb}=170, \mathrm{Cu}=86$, and $\mathrm{Zn}=540 \mu \mathrm{g} \cdot \mathrm{g}^{-1}$ ) above which sediments are considered as heavily polluted and adverse

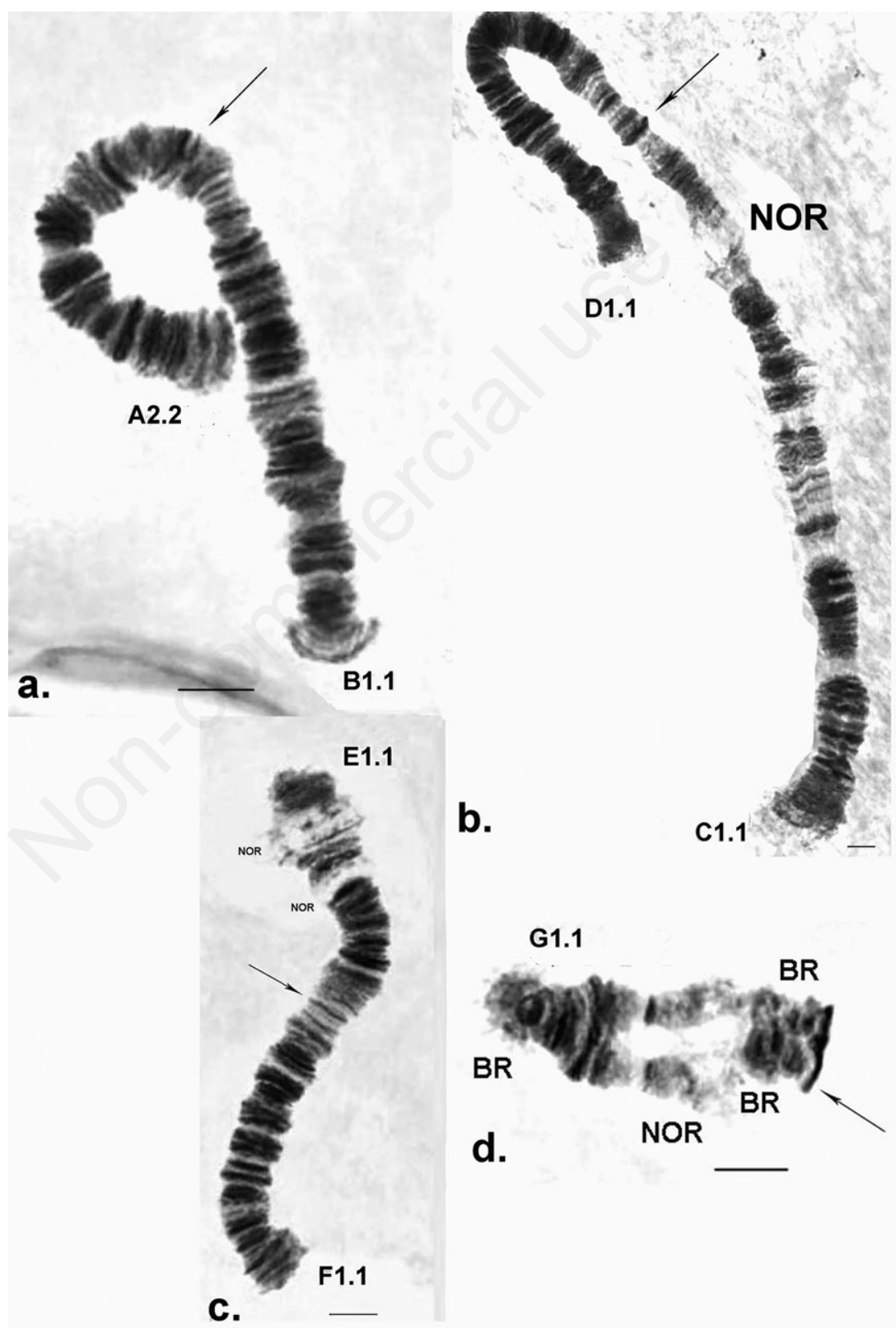

Fig. 2. Polytene chromosomes of Chironomus annularius. a) Chromosome A2.2 B1.1. b) Chromosome C1.1 D1.1. c) Chromosome E1.1 F1.1. d) Chromosome G1.1. The band sequences: A2.2 B1.1 C1.1 D1.1 E1.1 F1.1 G1.1 according to Kiknadze et al. (2012). Arrow indicates the centromere region. Scale bar: $10 \mu \mathrm{m}$. NOR, Nucleolar Organizer; BR, Balbiani ring. 


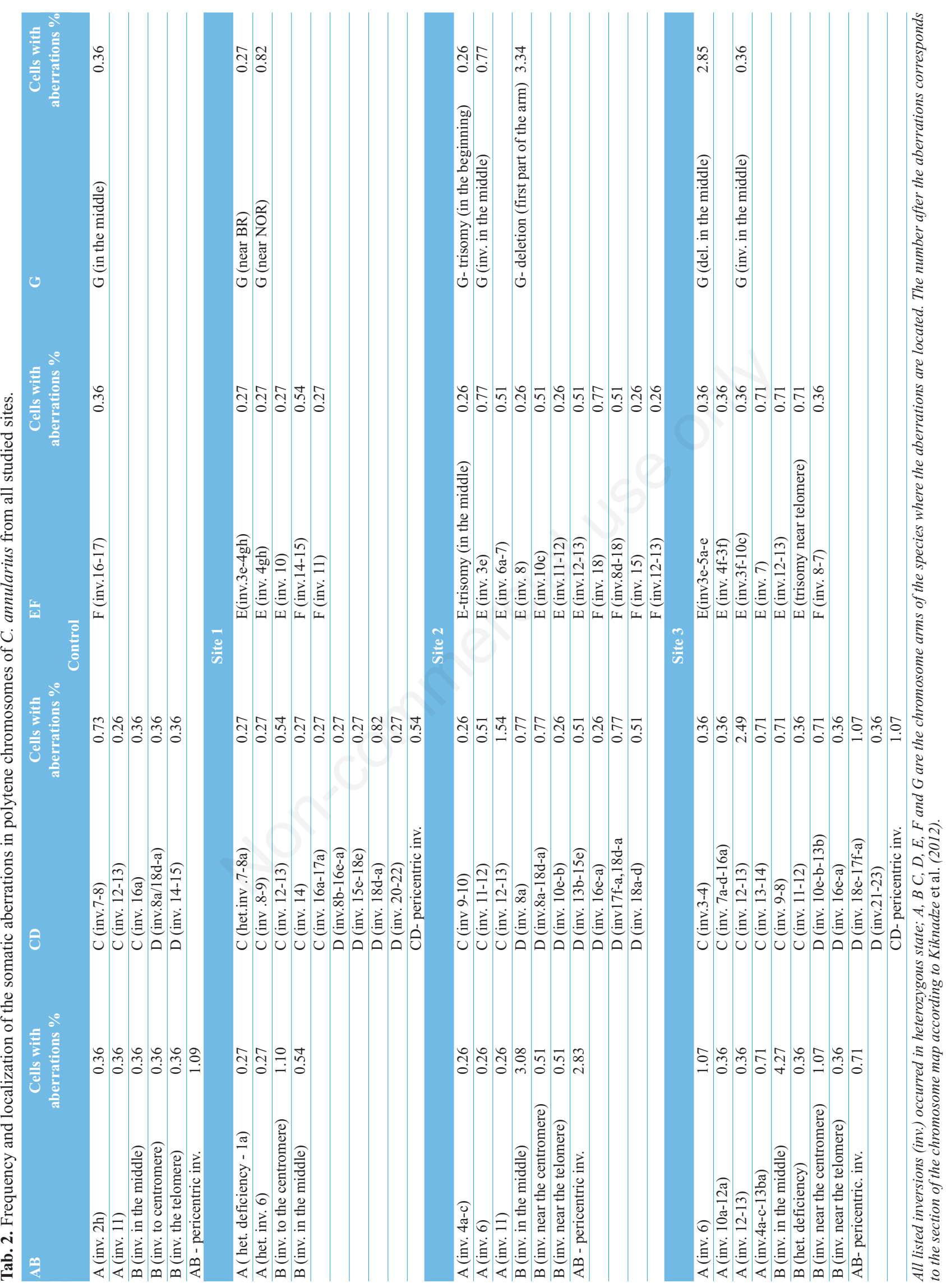


effects on sediment dwelling organisms are expected (Ministère de I'Environment du Quebec, 1992). The sediment of the control site at Saraya, also showed contamination by $\mathrm{Cd}$ and $\mathrm{Pb}$, according to Müller classification, although much lower than contamination observed in the Chechło river sites. This contamination may be a result of run-off from a nearby main road.

$C$. annularius genome from all polluted stations demonstrated a high level of chromosome variability as shown by the high frequency of inherited and somatic aberrations (Tab. 1). Seventeen out of 19 of the inherited aberrations were found in other Palearctic populations (Beliyanina, 1981; Petrova and Michailova, 1986; Kiknadze et al., 2012; Michailova and Hirvenoja, 2015) and occurred at almost the same frequency (between 7 and 50\%) (Kiknadze et al., 2012) as found in the studied

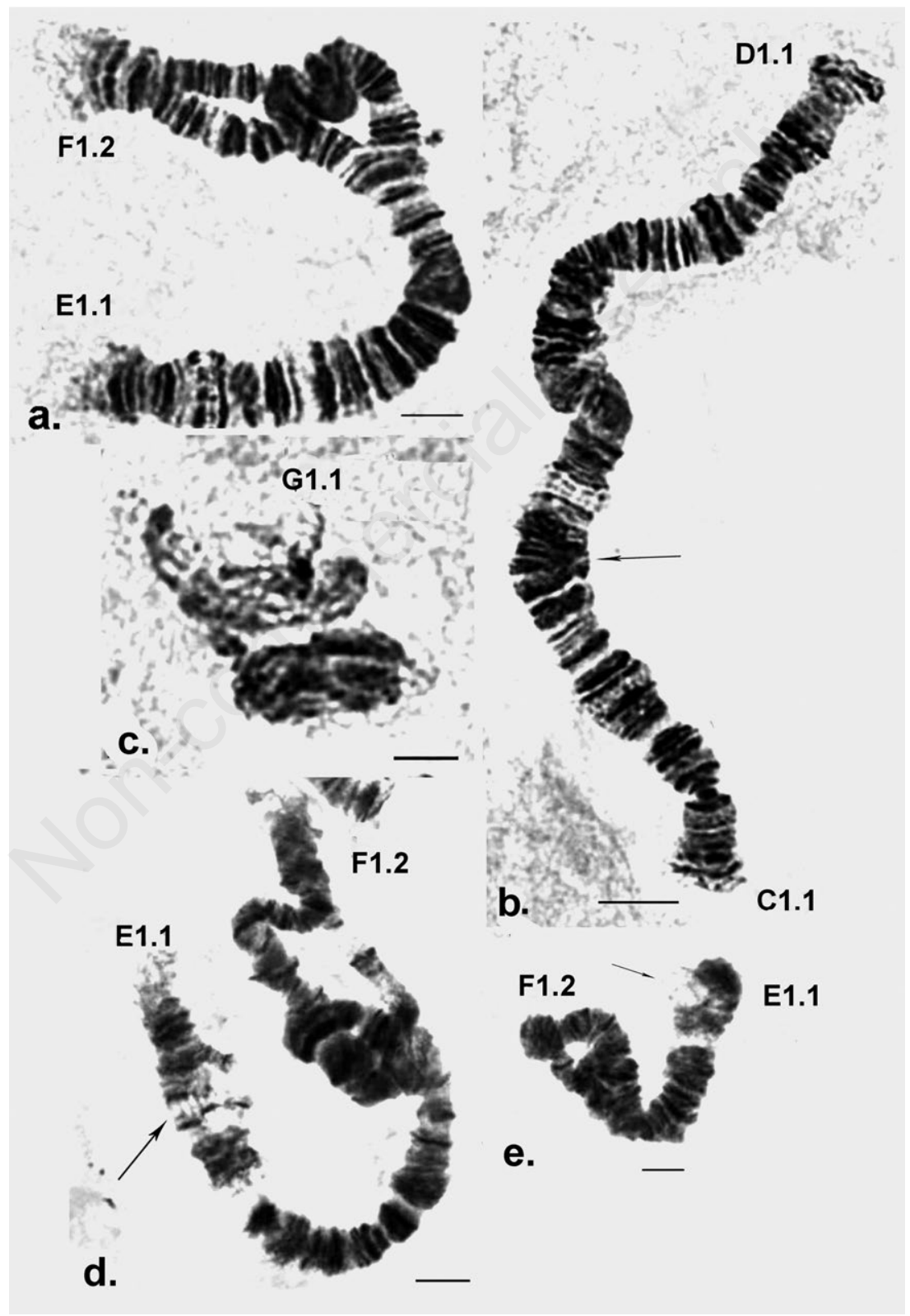

Fig. 3. Aberrations in the polytene chromosomes of Chironomus annularius. a) Inherited heterozygous inversion in arm F- F1.2. b) Somatic heterozygous inversion in arm C1.1, in the middle of the arm. c) Deletion in chromosome G1.1. d) Trisomy in arm E1.1 plus heterozygous inversion in arm F-F1.2. e) A heterozygous nucleolar organizer (NOR) in arm E1.1 plus heterozygous inversion in arm F-F1.2. Arrow indicates the chromosome aberrations. Scale bar: $10 \mu \mathrm{m}$. 
sites. The standard band sequences in arms A1.1, B1.1, C1.1, D1.1, E1.1 and G1.1 appeared in a high frequency in different Palearctic populations and are regarded as the main sequences of this species by Kiknadze et al. (2012). Similar band sequences: B1.1, C1.1, D1.1, E1.1 and G1.1 occurred at a high frequency in C. annularius from the River Chechło and are here designated as main sequences in these sites. It worth noting the high frequency of homozygous band sequences A2.2 (85\%) and the absence of the alternative standard sequences A1.1 in chromosome arm A of $C$. annularius collected from polluted sites. It is quite possible the chromosomal regions within this inversion to be contained blocks of genes that are coadapted in these combinations and preserved in the all polluted river sites occurring in a high frequency. This aberration is predominant in the Nearctic populations (Kiknadze et al., 2012). However, no relationship could be established between the $\mathrm{H}$ index and level of trace metals in the sediments. For instance, $\mathrm{H}$ index has the highest value in a site 3 which has less polluted sediments than site 2. Similar results were recorded in the model chironomid species $C$. riparius: the highest $\mathrm{H}$ index values were observed in populations with a relatively lower level of pollution (Sella et al., 2004).

Studies on the genome instability of various populations of C. piger (Michailova et al., 2015), C. riparius (Ilkova et al., 2014) and C. bernensis (Michailova et al., 2016) were successfully performed using cytogenetic indices. The present study extends these observations and demonstrates that these indices can be used as a model approach for examining the genotoxic potential of contaminants and measuring of the level of genome instability in a number of members of the genus Chironomus, including $C$. annularius. The values of $\mathrm{C}$ index reflect the high concentrations of trace metals in the studied sites. However, the $\mathrm{S}$ index showed some variation in its value in the polluted river sites. A possible reason may be that contamination by heavy metals may not be the only factor

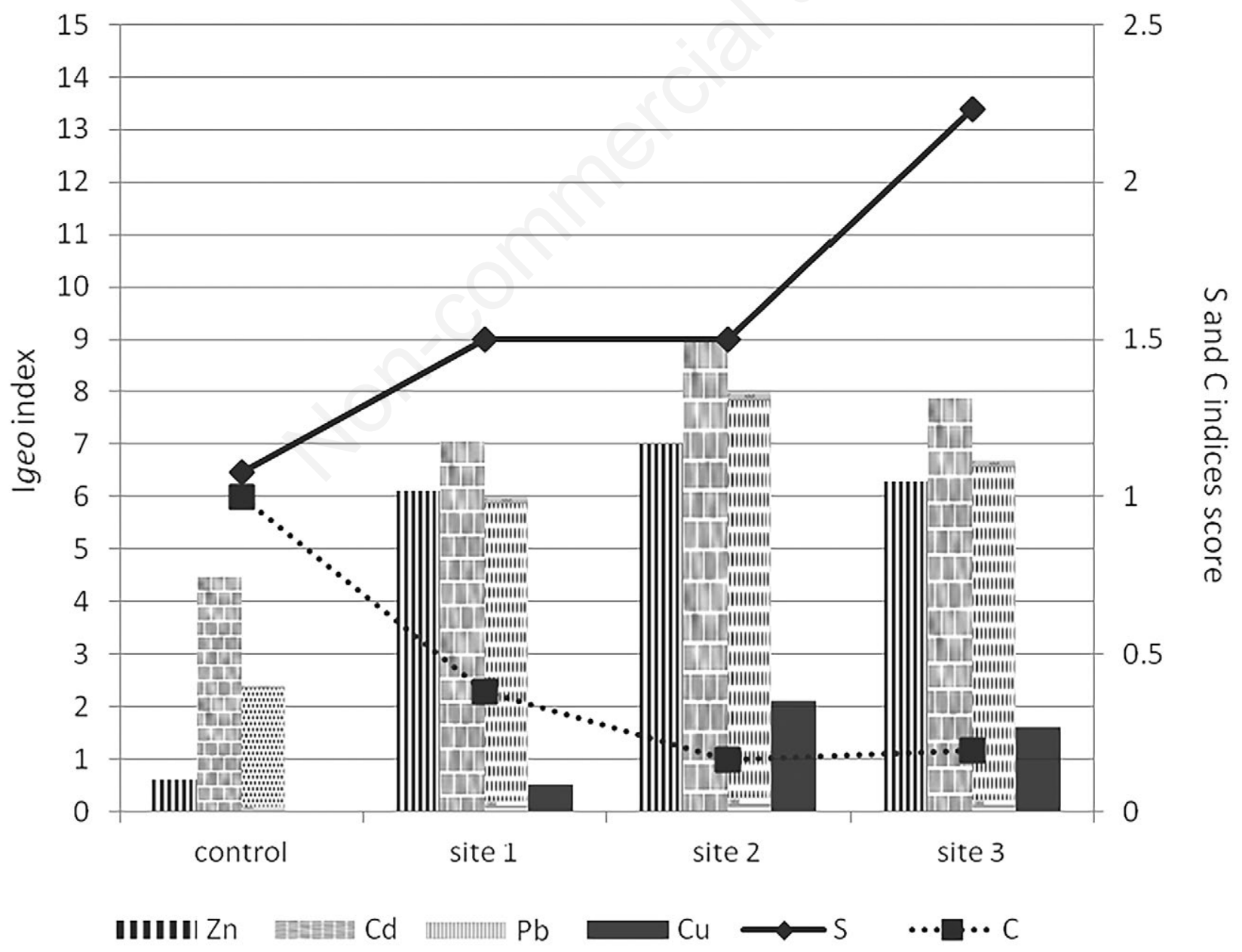

Fig. 4. The geoaccumulation index, cytogenetic (C) and somatic (S) indices in the polluted sites of River Chechło. 
inducing genotoxicity. Aquatic ecosystems are known as collectors of various contaminants and within the complex mixtures of pollutants a wide variety of interactions are possible (Baršiene, 2003). These interactions and the synergistic and antagonistic effects of a number of other toxicants could have affected the genotoxic response. In addition, trace metals will undergo a change in chemical speciation resulting in complexes which represent a risk of unknown magnitude.

The transcription activity of the Nucleolar Organizers was affected by heavy metals in the sediments of the Chechło River. Nucleoli are key structures which are highly conserved through the evolution, essential for maintenance of cellular and ribosomal production machinery (Planello et al., 2007) and very sensitive to trace metals (Michailova et al., 2012). The complete suppression of the transcription activity of many NORs in arms $\mathrm{C}$ and $\mathrm{E}$ was observed here for the first time in chironomids from polluted sites. Further molecular studies are necessary to understand mechanisms underlying NOR activity suppression.

Our study confirms that the Chironomid genome is a very sensitive structure and is much more responsive to toxicants than the larval external morphology. In the literature there are some contradictory opinions concerning the response of larval morphology to pollutants in the environment. Arambourou et al. (2014) noted very little phenotypic response to contaminated sediments and concluded that phenotypic defects in Chironomids are not a sensitive indicator of sediment contaminations. Al Shami et al. (2013), however, showed some larval malformations were induced by trace metals in the sediments. In contrast, the polytene chromosomes of every specimen we examined in this study were affected by contaminants in the environment.

\section{CONCLUSIONS}

The widely distributed Chironomid species $C$. annularius was utilized to monitor the environment of a trace metal-polluted river and together with model species such as $C$. piger and C. riparius could be used as a key species for biological monitoring. Additionally, the two indices applied in this study allow a sensitive approach to predicting the potential risk of persistent contaminants such as heavy metals before serious effects on the ecosystem occur.

\section{ACKNOWLEDGEMENTS}

This research was funded by National Science Center, Poland grant no. 2014/15/B/ST10/03862. The authors thank both reviewers and the editor for their valuable suggestions. The authors thank Prof. K. White, Manchester University for the linguistic revision.

\section{REFERENCES}

Adamu CI, Nganje TN, 2010. Heavy metal contamination of soil and surface water in the Arufu lead-zinc mining district, Middle Benue Trough, Nigeria. Ghana Mining J. 12:17-23.

Al-Shami SA, Salmah C, Rawi M, Nor M, Azizah S, Ahmad AH, Ishadi NA, Dieng H, 2013. Genotoxicity in Chironomus kiiensis (Chironomidae: Diptera) after exposure to polluted sediments from rivers of North Peninsular Malaysia: Implication for Ecotoxicological Monitoring. River Res. Appl. 29:1195-1204.

Arambourou H, Beisel JN, Branchu P, Debat V, 2014. Exposure to sediments from polluted rivers has limited phenotypic effects on larvae and adults of Chironomus riparius. Sci. Total Environ. 484:92-101.

Audry S, Schäfer J, Blanc G, Jouanneau JM, 2004. Fifty-year sedimentary record of heavy metal pollution $(\mathrm{Cd}, \mathrm{Zn}, \mathrm{Cu}$, $\mathrm{Pb}$ ) in the Lot River reservoirs (France). Environ. Pollut. 132:413-426.

Baršiene J, 2003. Cytogenetic damage in viviparid snails inhabiting different lakes in Switzerlands. Ekologija, $323-$ 328.

Beliyanina S, 1981. [Comparative karyological characteristics of Chironomus annularius (Diptera, Chironomidae) from different geographical regions].[Article in Russian]. Zool. Zh. 60:1030-1039.

Byrne P, Wood PJ, Reid I, 2012. The impairment of river systems by metal mine contamination: a review including remediation option. Crit. Rev. Env. Sci. Tec. 42:2017-2077.

Ciszewski D, 1997. Source of pollution as a factor controlling distribution of heavy metals in bottom sediments of Chechło River (south Poland). Environ. Geol. 29:50-57.

Ciszewski D, Aleksander-Kwaterczak U, Pociecha A, SzarekGwiazda E, Waloszek A, Wilk-Woźniak E, 2013. Small effects of a large sediments contamination with heavy metals on aquatic organisms in the vicinity of an abandoned lead and zinc mine. Environ. Monit. Assess. 185:9825-9842.

Förstner U, Salomons W, 1980. Trace metal analysis in polluted sediments. Environ. Technol. Lett. 1:1-494.

Ilkova J, Michailova P, Szarek-Gwiazda E, Kownacki A, Ciszewski D, 2017. The response of Chironomidae (Diptera) genome to heavy metal pollution in two rivers of Southern Poland. Acta Zool. Bulgar. Suppl. 8:9-15.

Ilkova J, Michailova P, Thomas A, White K, 2014. Genome instability of Chironomus riparius Mg. (Diptera, Chironomidae) from polluted water basins in Bulgaria. Ecologia Balkanica 5:1-8.

Keyl HG, 1962. [Chromosomenevolution bei Chironomus. II. Chromosomenumbanten und phylogenetische Beziehungen der Arten].[Article in German]. Chromosoma 13:464-514.

Kiknadze II, Istomina A, Golygina V, 2012. [The karyotype and chromosome polymorphism of the Holarctic species Chironomus annularius sensu Strenzke, 1959, (Diptera, Chironomidae)].[Article in Russian]. Evrasiatskiy Entomologicheskiy Zhurnal 11:95-114.

Michailova P, 1989. The polytene chromosomes and their 
significance for the systematics of family Chironomidae, Diptera. Acta Zool. Fennica (Helsinki) 186:1-107.

Michailova P, Hirvenoja M, 2015. Larval Morphology and karyotype of Chironomid larvae (Diptera, Chironomidae) from the brakish water of Tvarminne area, Finland. C. R. Acad. Bulg. Sci. 68:729-736.

Michailova P, Ilkova J, Dean AP, White KN, 2015. Cytogenetic index and functional genome alterations in Chironomus piger Strenzke (Diptera, Chironomidae) in the assessment of sediment pollution: A case study of Bulgarian and UK rivers. Ecotox. Environ. Safe. 111:220-227.

Michailova P, Ilkova J, White K, 2016. Implications of genome alterations in Chironomus bernensis Klotzli (Diptera) for assessment of trace metal pollution in two Bulgarian rivers. River Res. Appl. 32:914-924.

Michailova P, Sella G, Petrova N, 2012. Chironomids (Diptera) and their salivary gland chromosomes as indicators of trace metal genotoxicity. Ital. J. Zool. 79:218-230.
Ministère de l'Environment du Quebec, 1992. Interim criteria for quality assessment of St. Lawrence River sediment. Environment Canada, Ottawa.

Müller G, 1981. [Die Schwermetallbelastung der Sedimente des Neckars und seiner Nebenflüsse. Eine Bestandaufnahme]. [Article in German]. Chem. Ztg. 6:157-164.

Petrova N, Michailova P, 1986. Population-karyological studies of Chironomid species. Tsitologya 28:727-737.

Planello R, Martinez-Guitarte JL, Morcillo G, 2007. Ribosomal genes as early targets of cadmium-induced toxicity in Chironomus riparius larvae. Sci. Total Environ. 373:113-121.

Sella G, Bovero S, Ginepro M, Michailova P, Petrova N, Robotti C, Zelano V, 2004. Inherited and somatic variability in Palearctic populations of Chironomus riparius Meigen 1804 (Diptera, Chironomidae). Genome (Canada) 47:322-344.

Simpson SL, Batley GE, 2007. Predicting metal toxicity in sediments: A critique of current approaches. Integr. Environ. Assess. Manag. 3:18-31. 